\title{
PRICKLY-PEAR CACTUS ON THE CANADIAN PRAIRIES
}

M. G. MAW and M. M. MOLLOY, Agriculture Canada Research Station, Regina, Saskatchewan, S4P 3A2.

There are three species of cacti on the Canadian prairies: the pricklypears, Opuntia polyacantha Haw. and Opuntia fragilis (Nutt.) Haw. and the pincushion or ball cactus, Mamillaria vivipara (Nutt.) Haw. This paper considers only the two prickly-pear species because they are often considered to be unwanted or pest species. Cacti are found on dry hillsides and flatlands throughout the more arid parts of the Brown Soils Zone. Here soils are of poor quality, comprising a shallow layer over shale. These areas have some grazing capacity but have limitations that make improvement and cultivation impractical. For example, when the surface is disturbed, the soils are apt to erode and be blown about easily.

Some people are of the opinion that overgrazing increases cactus growth. However, this may be an illusion. Bement's study of heavy, moderate and light pasture use found that while populations of cactus doubled in area in 28 years, it never exceeded $2.4 \%$ of the land area. ${ }^{1}$ Removal of cactus did not significantly increase forage production but did make it more available to the cattle. In lightly grazed pastures, grass tended to mask the cactus while under heavy grazing the cactus was more conspicuous. Farmers near Avonlea, Saskatchewan, maintain that cactus has not extended its total range of growth much in the past 20 years.

Periodically, especially during droughts, prickly-pear cactus becomes a concern on the prairies. Ranchers then worry that the plant may displace valuable grass, use scarce moisture and cause injury to stock. During these periods various control methods are examined. Because spectacular control of cactus has been achieved in Australia through the introduction of the moth, Cactoblastis cactorum (Berg), biological control is often considered in other countries, including Canada.

In biological control programmes, preliminary studies are made to assess the problem and to determine what predators are already present and how effective they are in controlling pest populations. The following is a summary of insect surveys made from 1974 to 1979 on cactus in Saskatchewan and Alberta and of a study of two moths from Argentina as possible agents for cactus control.

\section{Survey of Insects Assoclated with Prickly-Pears}

The following insects were collected by aspirator or picked by hand from prickly-pear. Roots and fruit were not examined.

\section{ORTHOPTERA:}

Acrididae

Dissosteira venusta Stal - adult, Buffalo Pound, Sask., 29 May 1974. Peranabrus scabriollis (Thom.) adult, Val Marie, Sask., 16 May 1975.

HOMOPTERA:

Coccidae 


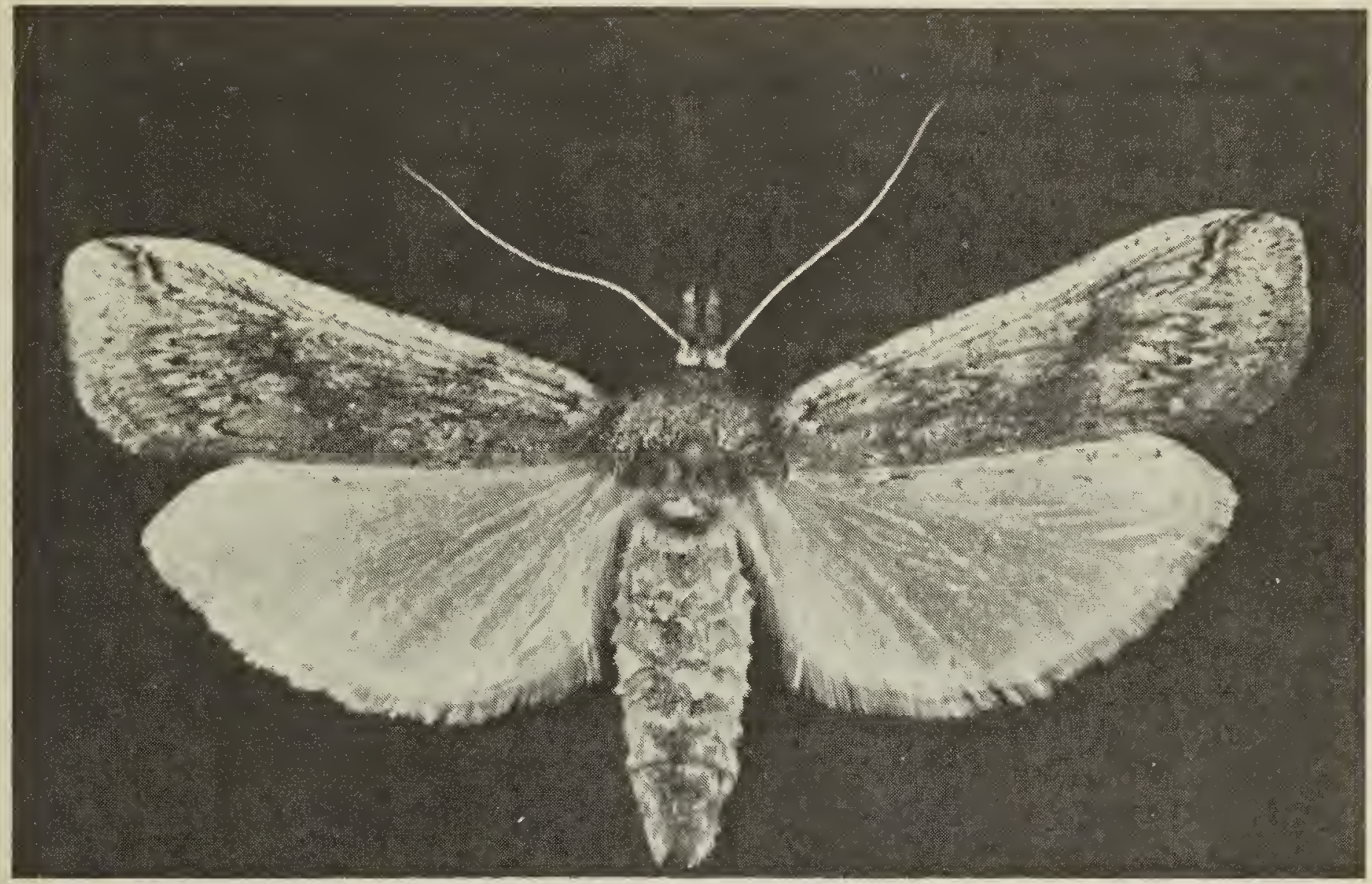

Fig. 1. Melitara dentata (Grote), a common cactus insect

M. M. Molloy

Dactylopius confusus (CK11.) - all stages, Buffalo Pound, Sask. - 29 May 1974. Avonlea, Sask. - 1 June 1974; 23 June 1977. Aylesbury, Sask. - June 1974; Manyberries, Alta. June, 1974. A widespread cactus mealybug. Most northerly recorded point, Aylesbury, Sask. Can be very destructive.

HEMIPTERA:

Coreidae

Chelinidea vittiger Uhler immatures, Irving, Alta. - 26 June, 1979. A gregareous feeder on the pads.

Chlorochroa uhleri Stal - adult, Val Marie, Sask. - 10 May 1973. A general plant feeder.

COLEOPTERA:

Carabidae

Microlestes linearis LeC. - adult, Val Marie, Sask. - 17 May 1975.

Melyridae

Collops vittatus Say - adult, Buffalo

Pound, Sask. - 7 July 1977.
Listrus provincialis Blais - adult, Irvine, Alta. - 26 June 1979.

Meloidae

Epicauta atrata (Fab.) - adult, Readlyn, Sask. - 2 July 1973.

Epicauta ferruginea Say - adult, Readlyn, Sask. - 2 July 1973, Buffalo Pound - 7 July 1977.

Anthicidae

Anthicus hastatus Casey - adult, Val Marie Sask. - 17 May 1975.

Nitidulidae

Carpophilus pallipennis Say - adult, Readlyn, Sask. - 2 June 1973, Avonlea, Sask. - 23 June 1977, Irvine, Alta. - 29 June 1977. In the flowers, very numerous.

Tenebrionidae

Hyperaspis sp. - adult Manyberries, Alta. - 19 June 1974. Melanastus sp. - adult, Manyberries, Alta. - 19 June 1974.

Elcodes obsoleta Say - adult, Val Marie, Sask. - 17 May 1975. 
Curculionidae

Gerstaekeris basalis LeC. - adult, Val Marie, Sask. - 17 May 1975, Eastend, Sask. - 10 June 1975. Breeds in cactus pads.

Bagous sp. - adult, Val Marie, Sask. - 17 May 1975.

\section{DIPTERA:}

Milichiidae

Milichia sp. - adult, Buffalo Pound, Sask. - 7 July 1975. Genus associated with decayed plant material.

\section{LEPIDOPTERA:}

Phycitidae

Melitara dentata (Grote) - larvae, Buffalo Pound, Sask. - 29 May 1974, Manyberries, Alta. - 19 June 1974, Avonlea, Sask. - 23 June 1977. Larvae mine the pads. Can be very destructful. About ten percent of pads in Saskatchewan and Alberta attacked.

Hesperiidae

Pyrgus communis Grote - adult, Irvine, Alta. - 26 June 1979.

\section{Blological Control Studles}

Agriculture Canada's Regina Research Station obtained two species of moth, Cactoblastis doddi Heinrich and Cactoblastis bucyrus Dyar, for biological control studies. Their origins were the high altitude valleys of Jujury province in northern Argentina. In the laboratory both species fed on Canadian prickly-pear but it was necessary to injure the pads before the larvae would enter and feed. Once inside, the larvae hollowed the pads but would not leave to go to fresh ones when there was no more food. Failure to leave the depleted pads is contrary to their habits in Argentina where they move from pad to pad as conditions dictate. Either the Canadian cactus was unsuitable or the insects were diseased for both species became weak and died out after a few generations in the laboratory.

\section{Dlscussion and Conclusions}

No further introductions of cactus insects are planned. C. doddi and C. bucyrus apparently are not suited to our Canadian cacti. Other species could, however, be tested. It appears that any harm or inconvenience caused by our prairie cactus is balanced by benefits derived from it. The native biotic agents already exert considerable pressure on the cactus and our native grasses are well able to compete satisfactorily when the land is not overgrazed.

The value of cactus in the ecosystem has not always been appreciated. During drought or under heavy grazing, cactus reduces soil erosion. Clumps of cactus conserve moisture by holding snow, and after summer showers, the soil within the clumps remains moist for several hours longer than soil surrounding them. The clumps slow runoff and protect seeds of desirable plants so necessary for repopulating the range after severe drought or heavy grazing. ${ }^{2}$

Prickly-pear provides food for at least 44 species of birds and mammals. The seeds may account for $65 \%$ of the diet of the Harris ground squirrel and up to $5.0 \%$ of the browse of deer and antelope. ${ }^{3}$ During the summer, cactus may constitute $30 \%$ of the food of the black-tailed jack rabbit $^{4}$ and is the main food of the pocket gopher ${ }^{5}$.

The introduction and release of a biotic agent to control prickly-pear in Canada would be vigorously opposed by both the United States and Mexican authorities because they regard cacti as an emergency fodder for cattle, and as human food. 
'BEMENT, R. E. 1968. Plains prickly-pear; relation to grazing intensity and blue grama yield on Central Great Plains. J. Range Manage. 19:83-86.

${ }^{2}$ HOUSTON, W. R. 1963. Plains pricklypear, weather, and grazing in the Northern great plains. Ecology 44:569-574.

3MARTIN, A. C., H. S. ZIM and A. L. NELSON. 1961. American wildlife and plants. A guide to wildlife food habits Dover pubs. Inc. New York. 500 pp.

${ }^{4}$ SPARKS, D. R. 1968. Diet of black-tailed jack rabbits on sandhill range in Colorado. J. Range Manage. 21:203208.

${ }^{5}$ VAUGHAN, T. A. 1967. Food habits of the northern pocket gopher on shortgrass prairie. Am. Midld. Natur. 77:176-189.

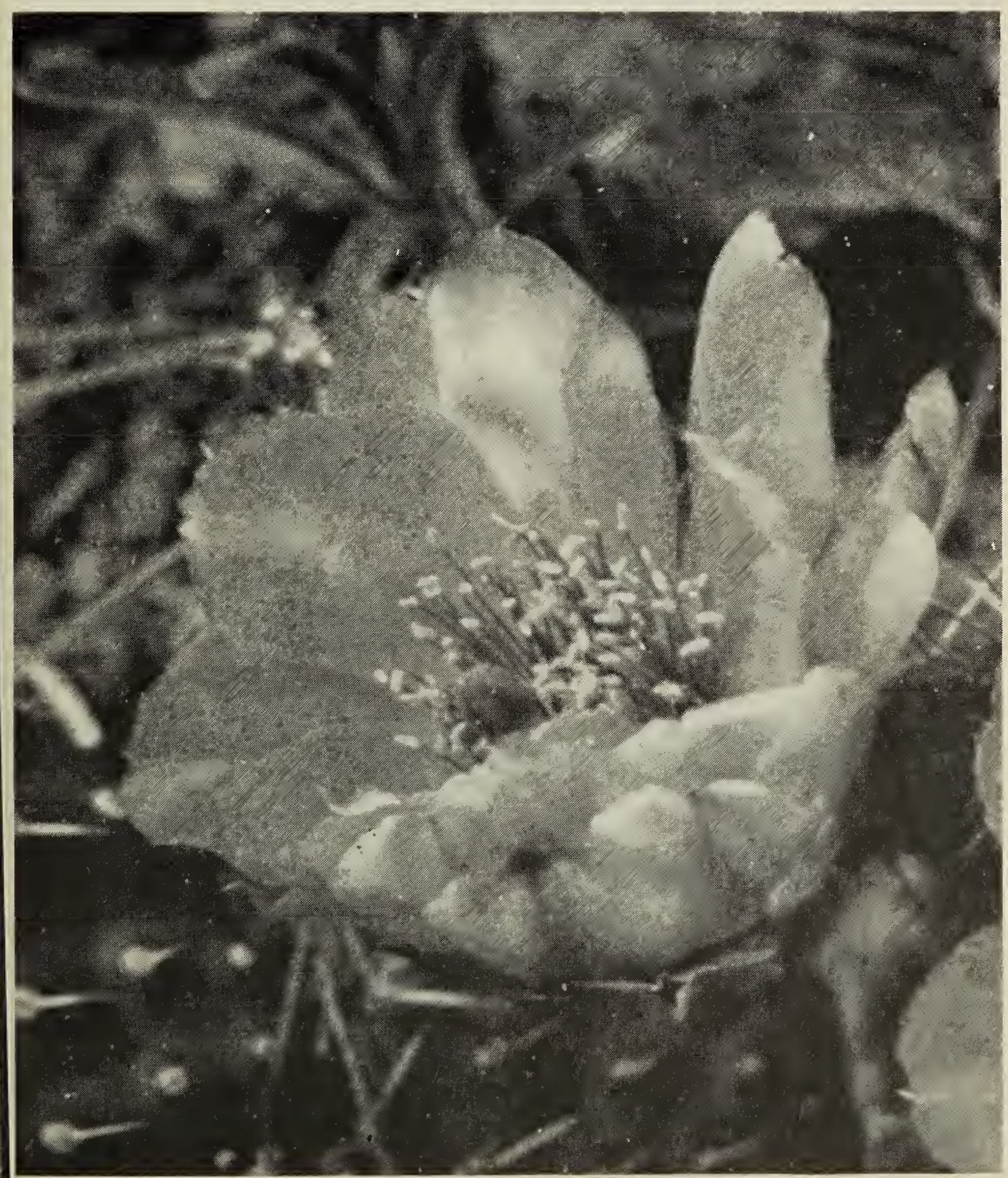

